\title{
Effects of Rainfall and Temperature Variability on Yam Production in Lafia Local Government Area, Nasarawa State, Nigeria
}

\author{
Anzaku M. Iliyasu' ${ }^{1}$, Buba Y. Alfred ${ }^{4}$, Alkali Mohammed ${ }^{2}$, L.M. Akpami ${ }^{3}$, Idris Abdulkareem ${ }^{3}$ \\ ${ }^{1}$ School of Continuing Education, Department of Sciences, Bayero University, Kano, Nigeria \\ ${ }^{2}$ Department of Environmental Sciences, Nasarawa State University Keffi, Nasarawa State, Nigeria \\ ${ }^{3}$ Department of Geography, Nasarawa State University Keffi, Nasarawa State, Nigeria \\ ${ }^{4}$ Nigerian Building \& Road Research Institute, 10 NBRRI Road/ I.T. Igbani Street, Jabi District, Abuja, FCT, \\ Nigeria
}

\begin{abstract}
The study assesses the effects of rainfall and temperature variability on yam production in lafia Local Government Area of Nasarawa State, Nigeria. The research data were collected from secondary data from the existed literatures such as textbooks, journals, articles, seminar papers, encyclopedia which are most pertinent to this study. The rainfall and temperature data of the fourteen years (2001-2014) were collected from synoptic weather station of NIMET archives Lafia sub station where rain gauge and thermometer are used. The Statistics Package for Social Science (SPSS) software was used for the analysis. The derivatives of these data were computed and used for further analysis such as average of number of rainy and temperature variations of months of years under study. The yam data was collected in metric tons as unit of measurement per year for the fourteen years under study which shows that there is an upward increase trend in yam production in the area of study over the time span in gradual and steady state which has a variation in production, across the years under consideration of $0.843 \%$. It is also indicated the effect of $0.186(19 \%)$ of the variation in yam production was explained by the variation in rainfall, maximum and minimum temperature between the study periods. It's further stated that the magnitude of effect by the predictors (rainfall, minimum and maximum temperature) on the dependent variable (yam) varies. Rainfall had a non-significant (P-value $>0.05$ ) effect of -0.269 and a coefficient value of -0.438 . This by extension implies that for every unit $(\mathrm{mm})$ decrease in rainfall over the period of time under investigation, yam production decreases by $-0.438 \mathrm{mt}$. The relationship between rainfall, temperature and yam using Pearson correlation shows that a weak negative relationship (-0.041) between rainfall and yam yield, a weak positive relationship (0.160) between maximum temperature and yam yield and there is a weak positive relationship (0.322) between minimum temperature and yam yield. The study identified increased production with non-significant positive effect of rainfall, maximum and minimum temperature on yam production. Since the study focused on the effects of rainfall and temperature variability on yam production in Lafia Local Government Area of Nasarawa state, without taking into consideration of other parameters like land use patterns and since rainfall and temperature are not the only parameters that affects yam production. the following recommendations are made: Agricultural Extension Officers (AEOs) should be deployed to guide farmers through routine visits, regular access to weather information to farmers by NIMET, application of irrigation for growing of crops, study of land use pattern should be considered and there is need for modern farm inputs and price control by government and Non Governmental organization.

Keywords: Effects, Rainfall, Temperature, Variability, Yam Production
\end{abstract}

DOI: $10.7176 / \mathrm{JEES} / 9-3-13$

Publication date:March $31^{\text {st }} 2019$

\subsection{Introduction}

Variability of temperature and Rainfall has been in history of earth changes of climate globally, regionally and locally. The un-stable natures are in various degrees of variations occurs as fluctuation, trends and unexpected changes to gradual changes of these climatic variables. Changes in climatic elements has become more threatening, not only to the stable development of socio-economic and agricultural practices of region or nation, but to the totality of existence of human Kind (Adejuwon, 2005). It is now not surprise on historical changes of climate where analysis of proxy data from tidal waves, changing sea and lake water levels, trace rights, pollen counts and ice-care occur on time scale of decades or more (Oladipo, (1991).

It has been established that variability in terms of trends or fluctuation of climate is a product of day to day atmospheric condition of a place which could lead to many years. But more importantly, the degree of changes in these magnitude and time being gave rise to climate variability (Ayoade, 2004).

The changes can be noise if the average weather conditions variability is small and climate anormalies when the changes are large (Ayoade, 2003).

Climatic parameters have an influence on all stages of agricultural production chain including land preparation, sowing, crop growth and management, harvesting, storage, transportation and marketing. Crop 
production is the integral of agricultural practices in which Rainfall (Moisture) and temperature are some of the main climatic elements influencing its production (Ayoade, 2004). Inter-annual variability has been the key climatic element that determines the success of agricultural practices in Guinea Savanna ecological zone of Nigeria (Ayanlade, 2009). Moisture highlighted spectacular role in agriculture in the tropics because of relatively high temperature throughout the year. The rates of evapotranspiration are constantly high with rainfall highly seasonal over most part of the region- tropics (Ayoade, 2004), and this study area lies within the zone. It was also observed that rainfall is the main determinant of the type of crops to be grown in a given region, the period of cultivation and general farming practices (Abaje et al, 2010).

It was also stated according to Alvaro et al (2009) that rain-fed farming dominates agricultural production in sub-Sahara Africa covering about $97 \%$ of the total crop land and exposes crops production to highly seasonal rainfall variability.

Agriculture in developing world is particularly vulnerable to changes in climatic elements, and can lead some African countries yield rain-fed agriculture reduced by up to $50 \%$ by the year 2020 (IPCC, 2001), and this was also affirmed by (Mastadrea et al, 2008) that central and South Asia crop yield could fall by up to $30 \%$ by 2050 as a result of climatic variations. There is still considerable uncertainty about the nature of climate trends where agricultural production depends on (even though there are other factors such as geosphere -soil types, soil depth, soil cover and other trace elements John, 1980) in which this study is considered only on two atmospheric condition- rainfall and temperature.

The threat rainfall and temperature caused variation on crop yield in a different season and was observed by (Adejuwan, 2005) that Nigeria experiences large spatial and temporal variation in rainfall and less variation in evapotranspiration. The change pattern of rainfall and temperature could influence the crop yield which many Nigerian farmers rely on to survive as such yam may lose its viability and many farmers will lose their source of income (Obasakin, 2006). It shows that deficiency in rainfall as major atmospheric determinant of crop production will affect greatly the yield of yam production.

It was also predicted by Nigerian Meteorological Agency (NIMET, 2011) that the whole country will experience late onset and early cessation with the increasing uncertainty. The onset, cessation and length of rainfall season, agriculture will be mostly affected which have similar prediction of 2016 by the same agency that the rainfall pattern will also experience delay onset early cessation less than the normal rainfall amount as well as dry spells in part of the country especially in the northernmost and during the rainy season with frequent occurrence and severe.

It is also indicated according to Bassey (2006) that $40 \%$ of Nigeria Gross National product (GNP) is obtained from agriculture and $70 \%$ of all African labour is employed in this sector. Invariably, agriculture carries major role of national income and consequently, any minor climate change or detoriation can cause a severe consequences on people livelihood especially agriculture that depends majorly on climatic elements especially radiation, temperature and moisture (rainfall) (Ayoade, 2004). On this background, the study is centered on effects of rainfall and temperature variability on yam production in Lafia Local Government Area of Nasarawa state for the period of 14 years (2001-2014).

\subsection{Materials and Methods}

The data were source from both primary and secondary sources and it's subjected to series of techniques in order to assess the effects of rainfall and temperature on yam production in Lafia Local Government Area of Nasarawa State, Nigeria. This research analysis techniques include coefficient of variation (CV), time series trend analysis to test tempospatial distribution pattern of rainfall and temperature, regression and correlation analysis to test the relationship between these climatic elements (rainfall and temperature) and yam; and the standardized coefficient of skewness $\left(Z_{1}\right)$ and kurtosis $\left(Z_{2}\right)$. The fisher's standardized coefficient of skewness $\left(Z_{1}\right)$ was used to test for the normality in rainfall and temperature distribution for further parametric analysis. The Statistics Package for Social Science (SPSS) software was used for the analysis.

\subsection{Results and Discussion}

\subsection{Analysis of rainfall for the growing season months}

The mean $((x))$, standard deviation $(S D)$, coefficients of variation $(C V)$, standardized coefficients of Skewness $\left(Z_{1}\right)$ and Kurtosis $\left(Z_{2}\right)$ of rainfall in the study area are presented in table 3.1 for the months of April to October. 
Table 1:Growing Season (April-October) Descriptive Statistics of Rainfall Trend (2001-2014)

\begin{tabular}{|c|c|c|c|c|c|c|c|}
\hline Variables & $\mathrm{N}$ & Mean & $\begin{array}{c}\text { Std. } \\
\text { Deviation }\end{array}$ & Variance & $\begin{array}{c}\text { Coefficient of } \\
\text { Variance }\end{array}$ & $\begin{array}{c}\text { Skewness } \\
\left(Z_{1}\right)\end{array}$ & $\begin{array}{c}\text { Kurtosis } \\
\left(Z_{2}\right)\end{array}$ \\
\cline { 2 - 8 } & Statistic & Statistic & Statistic & Statistic & Statistic & Statistic & Statistic \\
\hline April & 14 & 83.0429 & 40.34194 & 1627.472 & 48.579 & -0.468 & -0.152 \\
\hline May & 14 & 175.4571 & 27.64975 & 764.509 & 15.758 & -0.333 & 0.497 \\
\hline June & 14 & 177.1000 & 71.87085 & 5165.418 & 40.582 & 0.255 & 0.073 \\
\hline July & 14 & 239.7143 & 95.47849 & 9116.143 & 39.830 & -1.068 & 1.334 \\
\hline August & 14 & 267.0214 & 53.93406 & 2908.883 & 20.198 & 0.316 & -0.904 \\
\hline September & 14 & 211.4500 & 64.03698 & 4100.735 & 30.284 & 0.280 & -0.871 \\
\hline October & 14 & 133.6571 & 91.30207 & 8336.069 & 68.310 & 1.386 & 3.069 \\
\hline $\begin{array}{l}\text { Valid N } \\
\text { (listwise) }\end{array}$ & 14 & \multicolumn{7}{|l}{} & & \\
\hline
\end{tabular}

SPSS result extract.

Source: Research data analysis, 2018.

The data from the result extract in the table 3.1 reveals the descriptive statistics of monthly rainfall trend (AprilOctober), from the year 2001-2014. The standardized coefficients of Skewness $\left(Z_{l}\right)$ and Kurtosis $\left(Z_{2}\right)$, of monthly rainfall distribution trend was measured and presented in the table. Skweness measures whether or not a distribution is heavily weighted toward the right-end, or left-end of a scale, or the high-end or low-end of a scale. Kurtosis on the other hand is the measure of how flat or how peak a given distribution is. A given distribution is said to have Skewness or Kurtosis problem if its coefficient has a negative value less than -1.5 or a positive value more than 1.5. The result in the table thus indicates the absence of Skewness in the monthly rainfall distribution trend for the years under consideration. However, Kurtosis does exist in the distribution.

\subsection{Coefficient of Variation for annual rainfall.}

The coefficient of variation for the annual rainfall total in the study area is shown in table 4.2 Table .2: Coefficient of Variation for the Annual Rainfall Trend (2001-2014)

\begin{tabular}{|c|c|c|c|c|c|c|c|c|c|}
\hline \multirow{2}{*}{$\begin{array}{c}\text { Variable } \\
\text { s }\end{array}$} & \multirow{2}{*}{$\begin{array}{c}\mathrm{N} \\
\\
\text { Statisti } \\
\mathrm{c}\end{array}$} & \multirow{2}{*}{$\begin{array}{c}\text { Mean } \\
\text { Statistic }\end{array}$} & \multirow{2}{*}{$\begin{array}{c}\begin{array}{c}\text { Std. } \\
\text { Deviatio } \\
\mathrm{n}\end{array} \\
\text { Statistic }\end{array}$} & \multirow{2}{*}{$\begin{array}{l}\text { Variance } \\
\text { Statistic }\end{array}$} & \multicolumn{2}{|c|}{ Skewness } & \multicolumn{2}{|c|}{ Kurtosis } & \multirow{2}{*}{$\begin{array}{c}\begin{array}{c}\text { Coefficient } \\
\text { of Variance }\end{array} \\
\text { Statistic }\end{array}$} \\
\hline & & & & & $\begin{array}{c}\text { Statisti } \\
\text { c }\end{array}$ & $\begin{array}{c}\text { Std. } \\
\text { Erro } \\
\mathrm{r}\end{array}$ & $\begin{array}{c}\text { Statisti } \\
\mathrm{c}\end{array}$ & $\begin{array}{l}\text { Std. } \\
\text { Error }\end{array}$ & \\
\hline Rainfall & 14 & $\begin{array}{c}1287.442 \\
9\end{array}$ & 83.59991 & $\begin{array}{c}6988.94 \\
4\end{array}$ & -.057 & .597 & -.114 & $\begin{array}{c}1.15 \\
4\end{array}$ & $\begin{array}{c}6.49348487 \\
6\end{array}$ \\
\hline $\begin{array}{l}\text { Valid N } \\
\text { (listwise) }\end{array}$ & 14 & & & & & & & & \\
\hline
\end{tabular}

SPSS result extract.

Source: Research data analysis, 2018.

Coefficient of variation was used to calculate inter annual rainfall variability for the years under study. The result shows a coefficient of variation of $6.49 \%$, which shows that inter annual variation of rainfall between the years under study in Lafia LGA is not high. It also shows that the distribution of rainfall across the years under study is normal. Adejowon and Odekunle (2006) observed that rainfall distribution in Nigeria is generally normal if the mean is greater than $750 \mathrm{~mm}$. This shows that the distribution of rainfall in the study area is normal, since the annual mean is $1287.4 \mathrm{~mm}$.

\subsection{Annual Rainfall Trend Distribution in Lafia Local Government Area}

Figure 1 depicts a detailed account of the rainfall variability trend of the area of study. From the result, it can be observed that there was a decrease in annual rainfall from $1414.1 \mathrm{~mm}$ in 2001 , to 1180.9 in 2002 . This decrease was however quickly followed by an increase in the year 2003 by $1356.9 \mathrm{~mm}$. A careful observation of the result revealed that the 2004-2008 recorded a cyclical decrease in rainfall at $1305 \mathrm{~mm}, 1233 \mathrm{~mm}, 1280.1 \mathrm{~mm}, 1259$ and $1124.8 \mathrm{~mm}$ respectively. It is important to note here that the year 2008 recorded the lowest rainfall across the entire years under observation, at $1124.8 \mathrm{~mm}$. In general, yields may suffer significantly with either a late onset or early cessation of the growing season, as well as with a high frequency of damaging dry spells within the season, making the rainfall distribution unreliable (oladipoet, al.,2002 and NIMET 2011 predictions

Hence, it is obvious from the result that there has been an experience in the number of variation in rainfall in Lafia LGA over the period of time under consideration (2001-2014), with the highest rainfall recorded in the year 2009 at $1586.9 \mathrm{~mm}$, while the least amount of rainfall was recorded in the year 2008 at 1124.8 respectively. 
॥|다



Figure 1: Annual rainfall trend in Lafia LGA.

Source: NIMET.

The trend equation and trend line of the annual rainfall indicates a variation in rainfall across the years at $0.01 \%$. This by implication simply implies that the annual rainfall patter over the periods of 2001-2014 has been decreasing at a gradual rate.

The general decrease in annual rainfall may be due to the fact that some years recorded low rainfall which might have gradually influenced the overall trend. For instance, from the trend graph, it can be observed that the annual rainfall recorded in the area had the following data; $2002(1180.9 \mathrm{~mm}), 2005(1233 \mathrm{~mm}), 2007(1259.1 \mathrm{~mm})$, $2008(1124.8 \mathrm{~mm}), 2011(1252.1 \mathrm{~mm})$, and $2014(1254.9 \mathrm{~mm})$. This by implication simply implies that even though annual rainfall decreased over the time periods, the rate of decrease was gradual. The gradual declining records of rainfall in some periods of the years under consideration may be of great benefits to some to crop production, especially those crop that do not require excessive rainfall. However, for crops that require excessive amount of rainfall, this decline may become detrimental. It is also important to stress that the decrease in the amount of rainfall in the area of study may be due to low temperature which tends due to decrease in evapotranspiration rates. Low temperature ensures an appropriate amount of moisture in soil, which tends to have positive effects on crops.

3.4 Time Series on rainfall for the growing season month

To be able to get the time series of the rainfall variability, a monthly chart of the growing season;

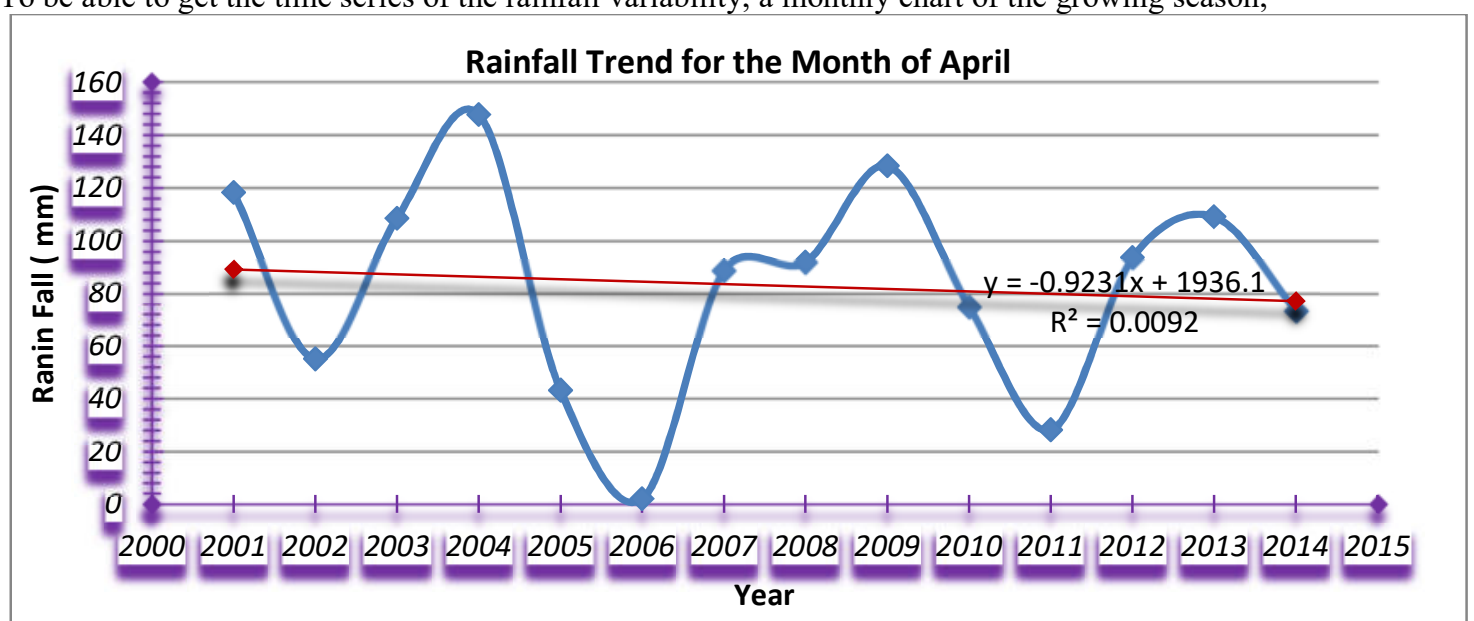

Fig. 2: April Rainfall Distribution for the years (2001-2014) -Onset of rainfall in the study area

Source: NIMET,

The figure 1 depicts the rainfall trend of the years under study, for the month of April. A carful look t the scatter plot shows that the year 2004 recorded the highest amount of rainfall for the month of April at 147.80mm, closely followed by the year 2009 at $128.30 \mathrm{~mm}$. The year 2006 recorded the lowest amount of rainfall for the month, at $1.90 \mathrm{~mm}$, while year 2011 had $28.10 \mathrm{~mm}$ of rainfall. The trend equation and trend line of the annual rainfall indicates a gradual decreasing trend $(0.041 \mathrm{x})$.

Figure 2 shows the rainfall trend for the month for years under study. From the results, it can be observed that the month of May for years under study experienced a positive linear rainfall. The year 2001, 2006, 2011 and 
2014, recorded rainfall above the Mean Standard Deviation for the entire years under study at; $0.087 \mathrm{x}$, while the years 20002, 2003, 2004, 2005 2007, 2010, and 2013 recorded rainfall below the Mean Standard Deviation. The variation in rainfall for this month for the given years under study was $0.001 \%$ as indicated by; $\mathrm{R}^{2}=0.001$.

The positive rainfall distribution in the month of May is good for the development of yam. Active process of yam germination and development of root and vine, take place in the first three month of planting. Therefore, increase in rainfall in the month of May support high yield of yam.

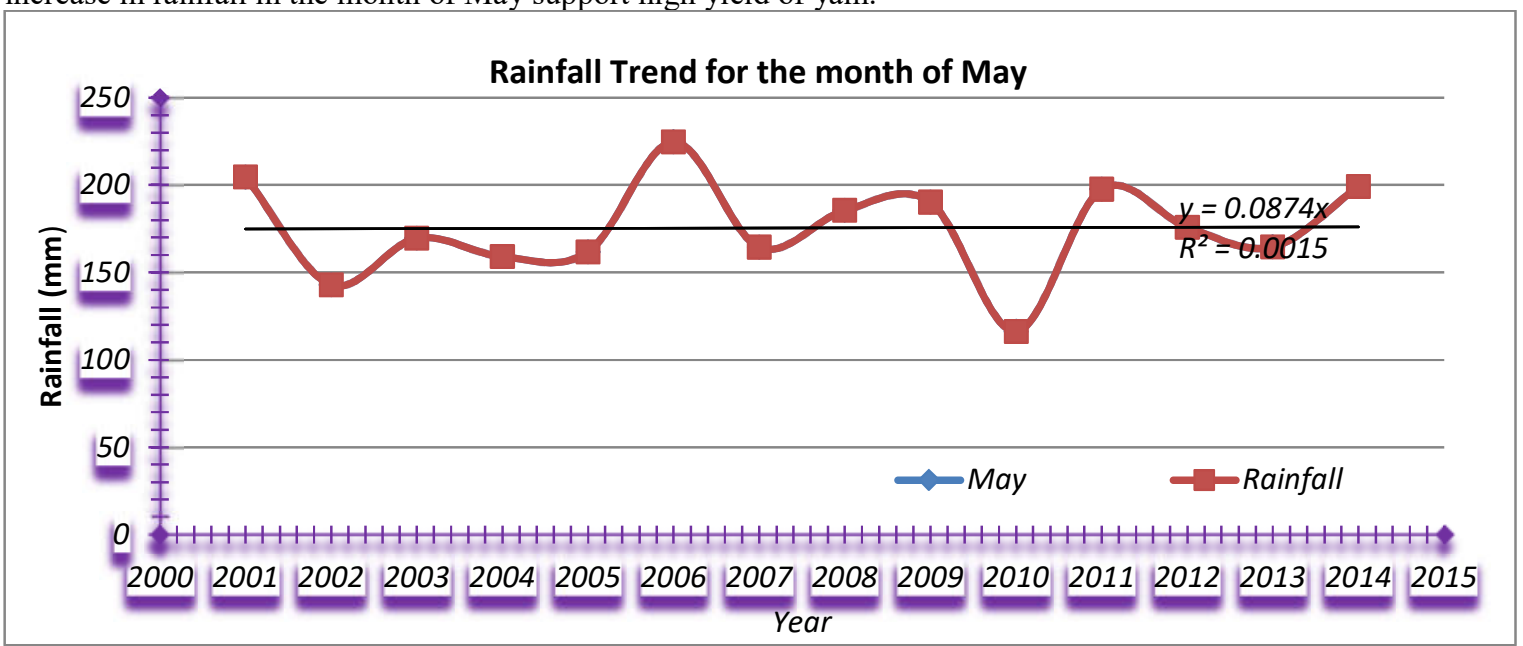

Fig. 3: May Rainfall Distribution for the years 2001-2014

Source: NIMET,

Figure 3 shows the rainfall distribution for the month of June for the years under study. From the results, it can be observed that the month of June for years under study experienced a positive upward rainfall trend. The year 2001, 2007, 2009, 2011, and 2012, recorded rainfall above the Mean Standard Deviation for the entire years under study at; $y=2.417 x-4676$, while the years 2002, 2003, 2004, 2005 2006, 2010, 2013 and 2014 recorded rainfall below the Mean Standard Deviation. The variation in rainfall for this month for the given years under study was $0.019 \%$ as indicated by; $\mathrm{R}^{2}=0.019$

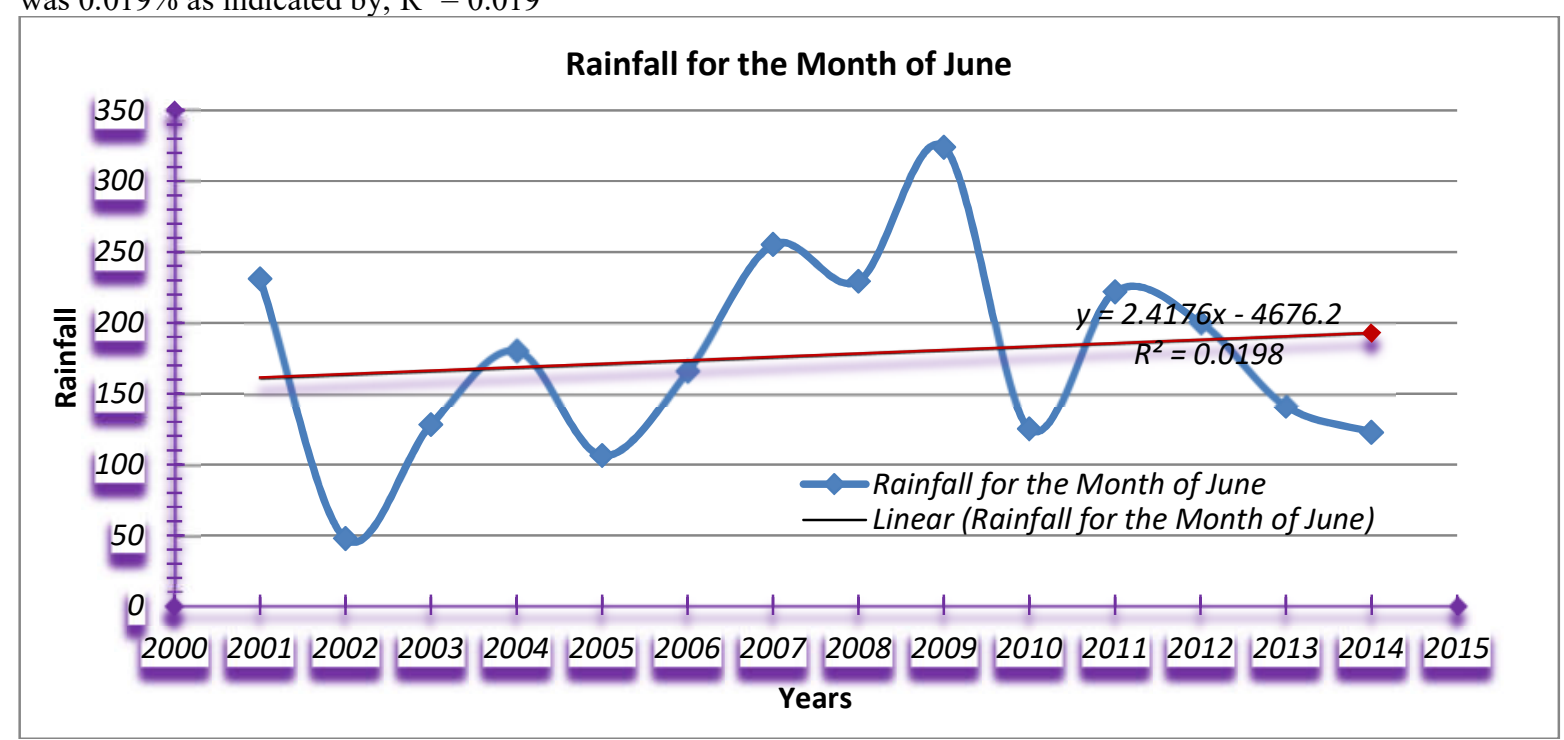

Fig. 4: June Rainfall Distribution for the years 2001-2014.

Source: NIMET,

Figure 4 shows the rainfall distribution for the month of July for the years under study. From the results, it can be observed that the month of July for years under study experienced a negative downward rainfall trend. The year 2002, 2004, 2006, 2010, and 2013, recorded rainfall above the Mean Standard Deviation for the entire years under study at; $y=-4.533 . x+9341$, while the years 20001, 2003, 2004, 2005 2007, 2008, 2009, 2011,2012 and 2014 recorded rainfall below the Mean Standard Deviation. The variation in rainfall for this month for the given years under study was $0.039 \%$ as indicated by; $\mathrm{R}^{2}=0.039$. 


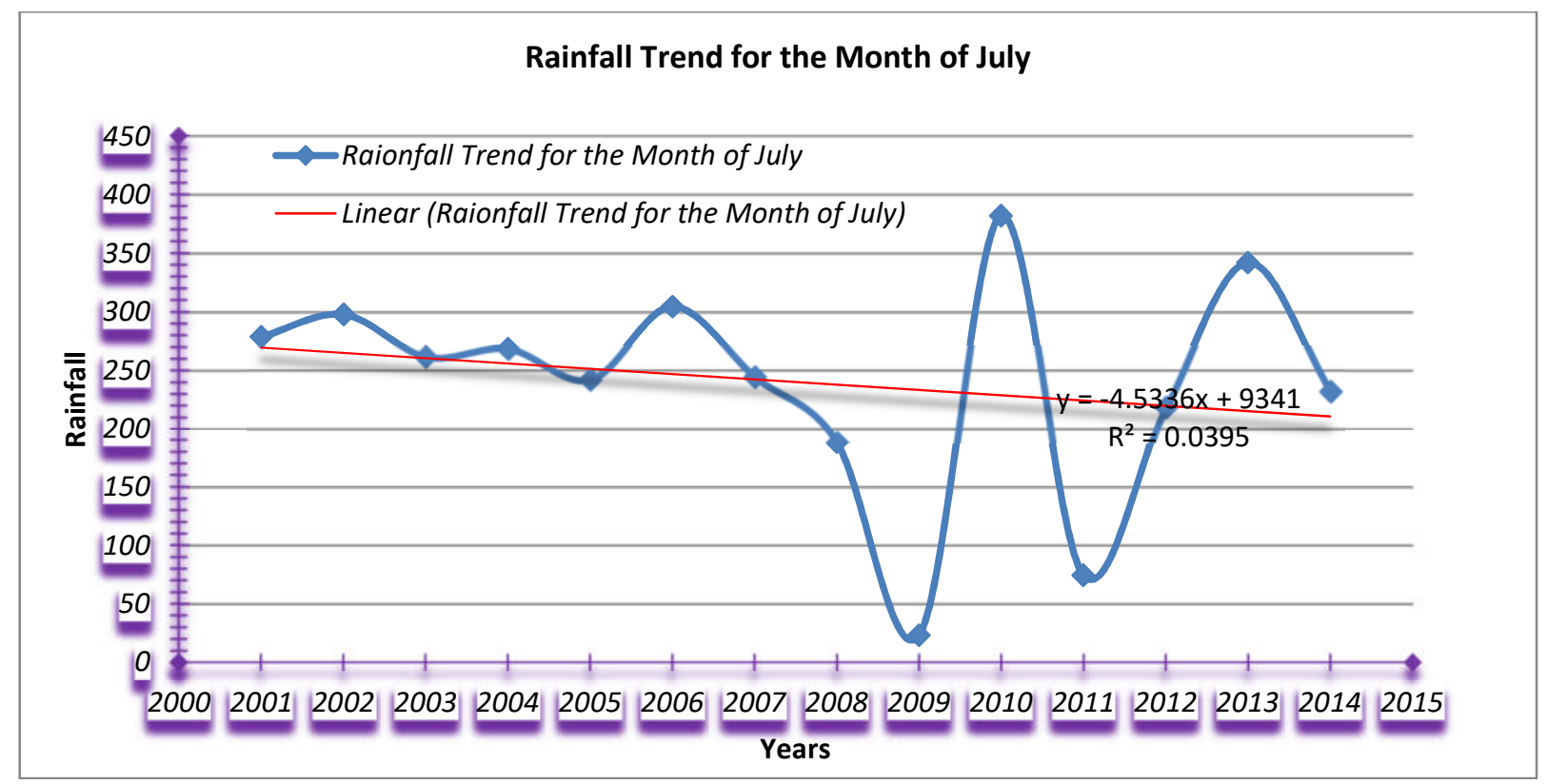

Fig. 5: July Rainfall Distribution for the years 2001-2014.

Source: NIMET,

The rainfall distribution trend for the month August for the years under study indicates a negative rainfall trend, as depicted in figure 4.6. From the results, it can be observed that the year 2001, 2002, 2005, 2011, and 2014, recorded rainfall above the Mean Standard Deviation for the entire years under study at; $y=-5.233 \mathrm{x}+$ 10733, while the years 2003, 2004, 2006, 2007, 2008, 2009, 2010, 2012, 2012 and 2013 recorded rainfall below the Mean Standard Deviation. The variation in rainfall for this month for the given years under study was $0.164 \%$ as indicated by; $\mathrm{R}^{2}=0.164$.

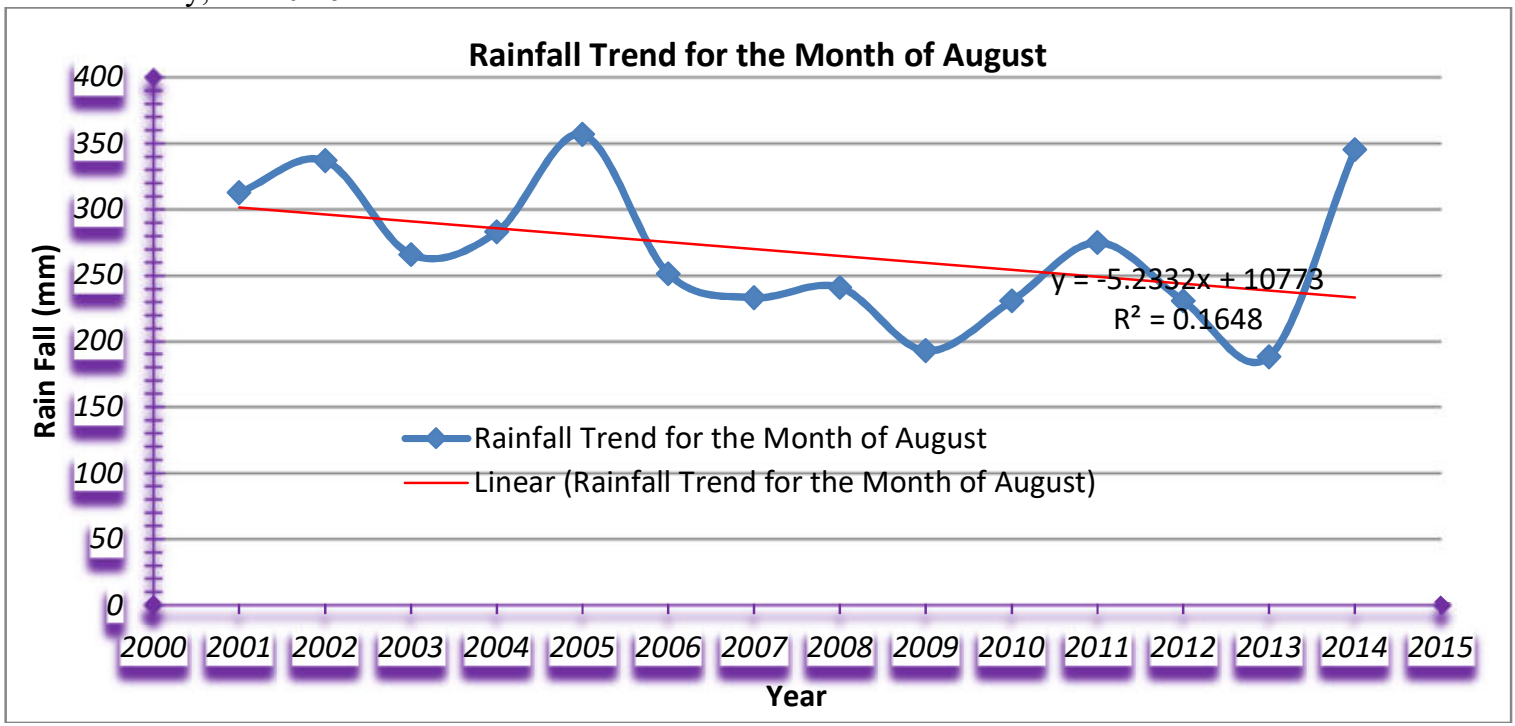

Fig. 6: August Rainfall Distribution Trend for the Years 2001-2014.

Source: NIMET,

The rainfall distribution trend for the month September for the years under study indicates a linear negative rainfall trend, as depicted in figure 1.3.8. From the results, it can be observed that the year 2003, 2006, 2007, 2010, 2011 and 2013, recorded rainfall above the Mean Standard Deviation for the entire years under study at; $y=-$ $0.431 \mathrm{x}+1078$, as it was stated by Bamike, (2010) during the rainy season, the zone of the ITD follows the Sun northward, as a result, more and more of the country comes under the influence of moisture-laden tropical maritime air. Thus, much of the country experiences a rainy season between the months of June and September. The years 2003, 2004, 2006, 2007, 2008, 2009, 2010, 2012, 2012 and 2013 recorded rainfall below the Mean Standard Deviation. The variation in rainfall for this month for the given years under study was $0 . .0 \%$ as indicated by; $\mathrm{R}^{2}=$ 
0.00 . which can also attributed to either a late onset or early cessation of the growing season, as well as with a high frequency of damaging dry spells within the season, making the rainfall distribution unreliable (oladipoet, al.,2002) this was affirmed by the prediction of NIMET 2011 and 2016 respectively.

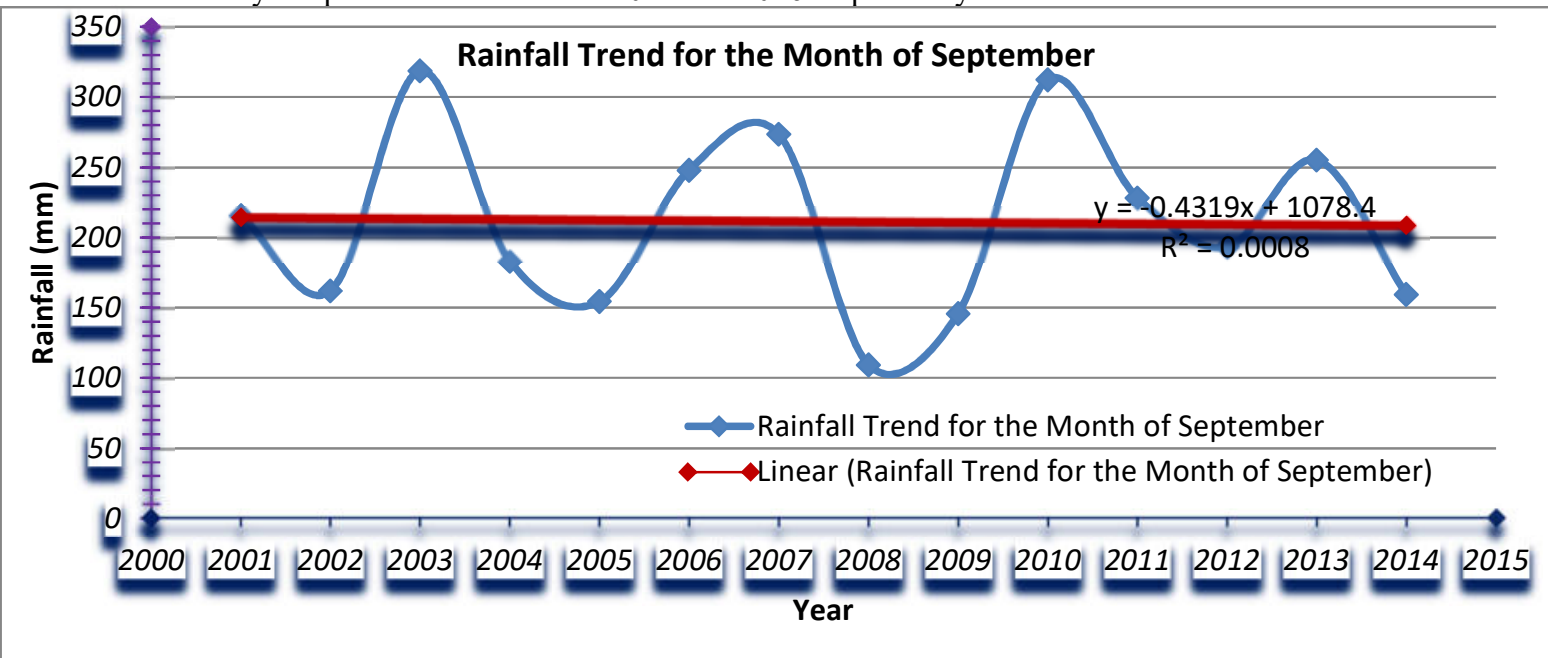

Fig. 7: September Rainfall Distribution Trend for the Years 2001-2014.

Source: NIMET

Figure 7 depicts the rainfall distribution trend for the month October, for the years under study. a careful look at the trend indicates an upward positive increase in rainfall trend over the spread of years for the month of October. From the results, it can be observed that the year 2009, and 2011, recorded rainfall above the Mean Standard Deviation for the entire years under study at; $y=6+.300 x-12514$, while the years 2001, 2002, 2003, 2004, 2005, 2006, 2007, 2008, 2010, 2012, 2013 and 2014 recorded rainfall below the Mean Standard Deviation. The variation in rainfall for this month for the given years under study was $0.083 \%$ as indicated by; $\mathrm{R}^{2}=0.083$.

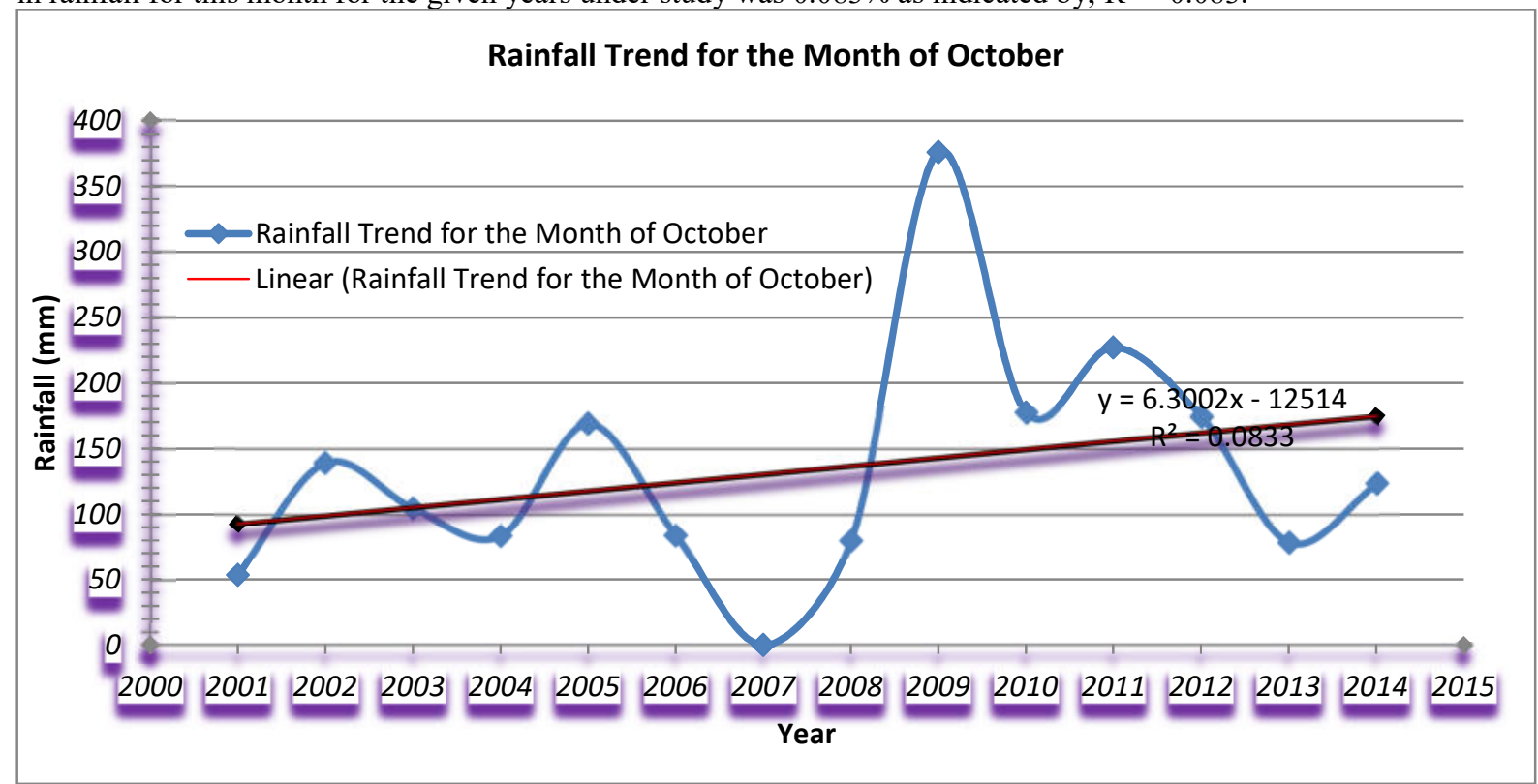

Fig. 8: October Rainfall Distribution Trend for the Years 2001-2014.

Source: NIMET

\subsection{Temperature Trend in Lafia Local Government Area}

4.1 Maximum temperature in Lafia Local Government Area.

In determining trend, the temperature variables were subject to trend analyses via the Microsoft Excel function of trend. From the trend in figure 9, it is quite evident that the maximum temperature has been on a constant variation over the period of study. This oscillate behaviour is most notably between the years 2004-2013 of the period under study. There was a decline Maximum temperature recorded in the year 2004 at $407.1^{\circ} \mathrm{c}$ compared to that of the 
years 2001,2002 and 2003 , at $407.7^{\circ} \mathrm{c}, 412.1^{\circ} \mathrm{c}$ and $411.6^{\circ} \mathrm{c}$ respectively. The years $2005-2008$ recorded a steady rise in maximum temperature, at; $411.2^{\circ} \mathrm{c}, 414.9^{\circ} \mathrm{c}, 417.1^{\circ} \mathrm{c}$ and $420.7^{\circ} \mathrm{c}$. A steady decline in maximum temperature was recorded between the years $2009-2013$, at; $418.1^{\circ} \mathrm{c}, 416^{\circ} \mathrm{c}, 408.3^{\circ} \mathrm{c}, 403.5^{\circ} \mathrm{c}$ and $403.3^{\circ} \mathrm{c}$ respectively. The year 2014 recorded the highest increase in maximum temperature in Lafia LGA at $445.6^{\circ} \mathrm{c}$. Thus the trend equation shows variation in maximum temperature trend at $0.103 \%$. at this results Ayoade, 2004 stated that The main reason for this seasonal temperature uniformity is the small differences in the amount of net radiation received in the different seasons. The temperature uniformity is strongest around the equator and decreased pole wards with increasing latitude. Towards the outer limits of the tropics thermal differences with place increase rapidly especially over the continental areas figure 2.8. It was written by Binbol noted the high radiation income in this part of the globe, which is also evenly distributed throughout the year, also accounts for the high temperature recorded in the state (Binbol et al., 2007)and NIMET 2011 and 2016), predicts the increase in the atmospheric heat in the day and nocturnal temperature decreasing.

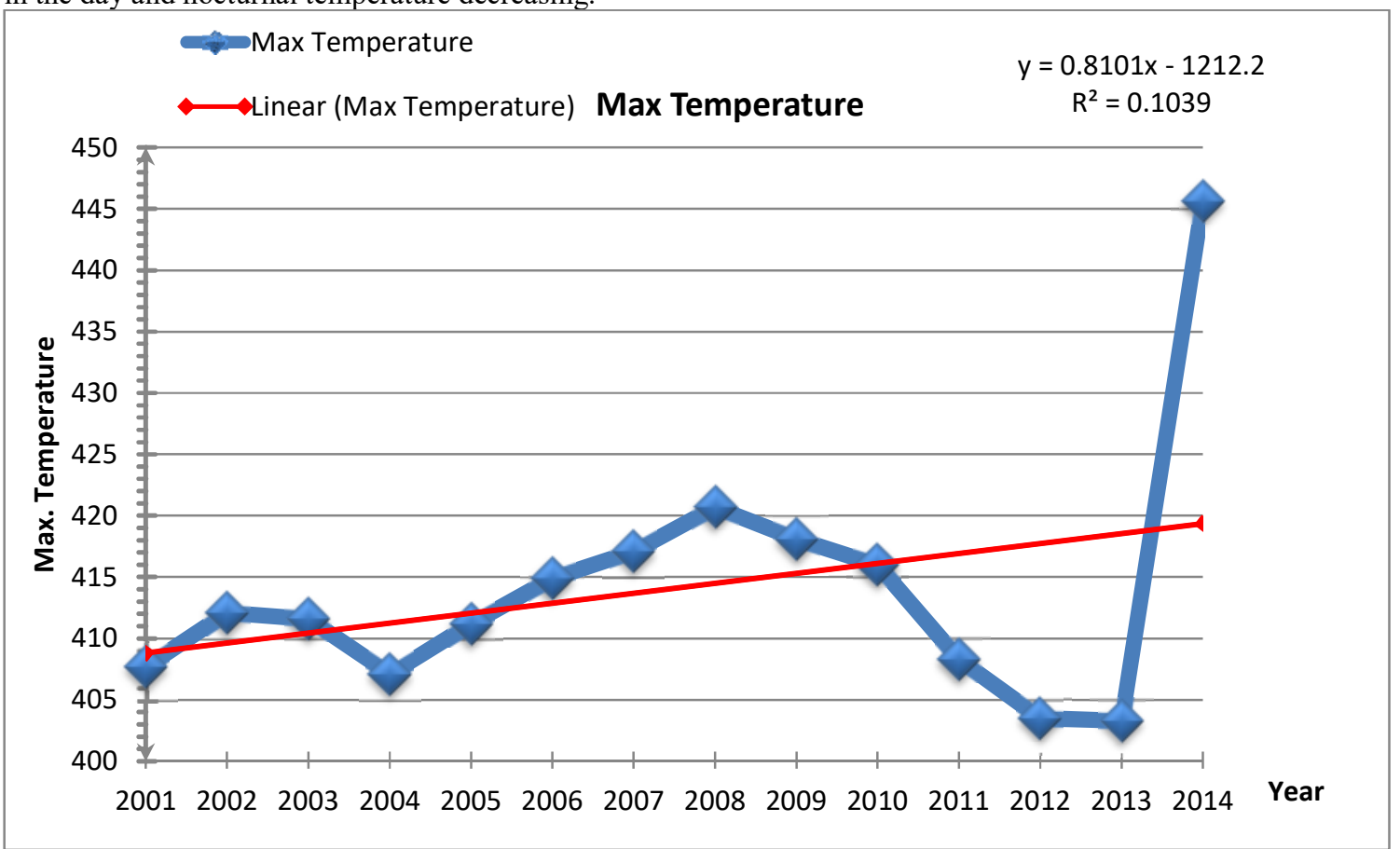

Figure 9: Maximum temperature trend in Lafia LGA. Source: field work, 2016. Source: NIMET

4.2 Minimum Temperature in Lafia Local Government Area.

Figure 10 depicts the minimum temperature trend in Lafia Local Government Area. A careful look shows at the figure suggest a cyclical trend in minimum temperature in the area of study over the time span. A gradual and steady increase in minimum temperature was recorded within the periods of $2001-2006$ at $263.5^{\circ} \mathrm{c}, 265.9^{\circ} \mathrm{c}$, $270.2^{\circ} \mathrm{c}, 273.9$ and $276.3^{\circ} \mathrm{crespectively.} \mathrm{However,} \mathrm{it} \mathrm{is} \mathrm{important} \mathrm{to} \mathrm{note} \mathrm{that} \mathrm{within} \mathrm{these} \mathrm{periods;} \mathrm{only} \mathrm{the} \mathrm{year}$ 2004 recorded and slight dip in minimum temperature, at $266.9^{\circ} \mathrm{c}$. A steep decline in minimum temperature was recorded for the year 2007 and 2008 , at $252.6^{\circ} \mathrm{c}$. and $251.1^{\circ} \mathrm{c}$. The year 2009 and 2010 however, recorded an astronomical increase in minimum temperature, with the 2010 having the highest record of minimum temperature at $289.1^{\circ} \mathrm{c}$. A slight constant decrease occurred in 2011 and 2012 at $270.9^{\circ} \mathrm{c}$, respectively, while a minimal increase was recorded in 2013 and 2014 , at; $276.7^{\circ} \mathrm{c}$, and $272.7^{\circ} \mathrm{c}$. The trend equation and trend line indicates the variation in minimum temperature trend at $0.107 \%$ in Lafia Local Government Area over the period under study.

The implication here is that an increase in minimum temperature to crop will affect photosynthetic activities of crops which may in the long run affect the yield of crops (Ayoade, 2004). 


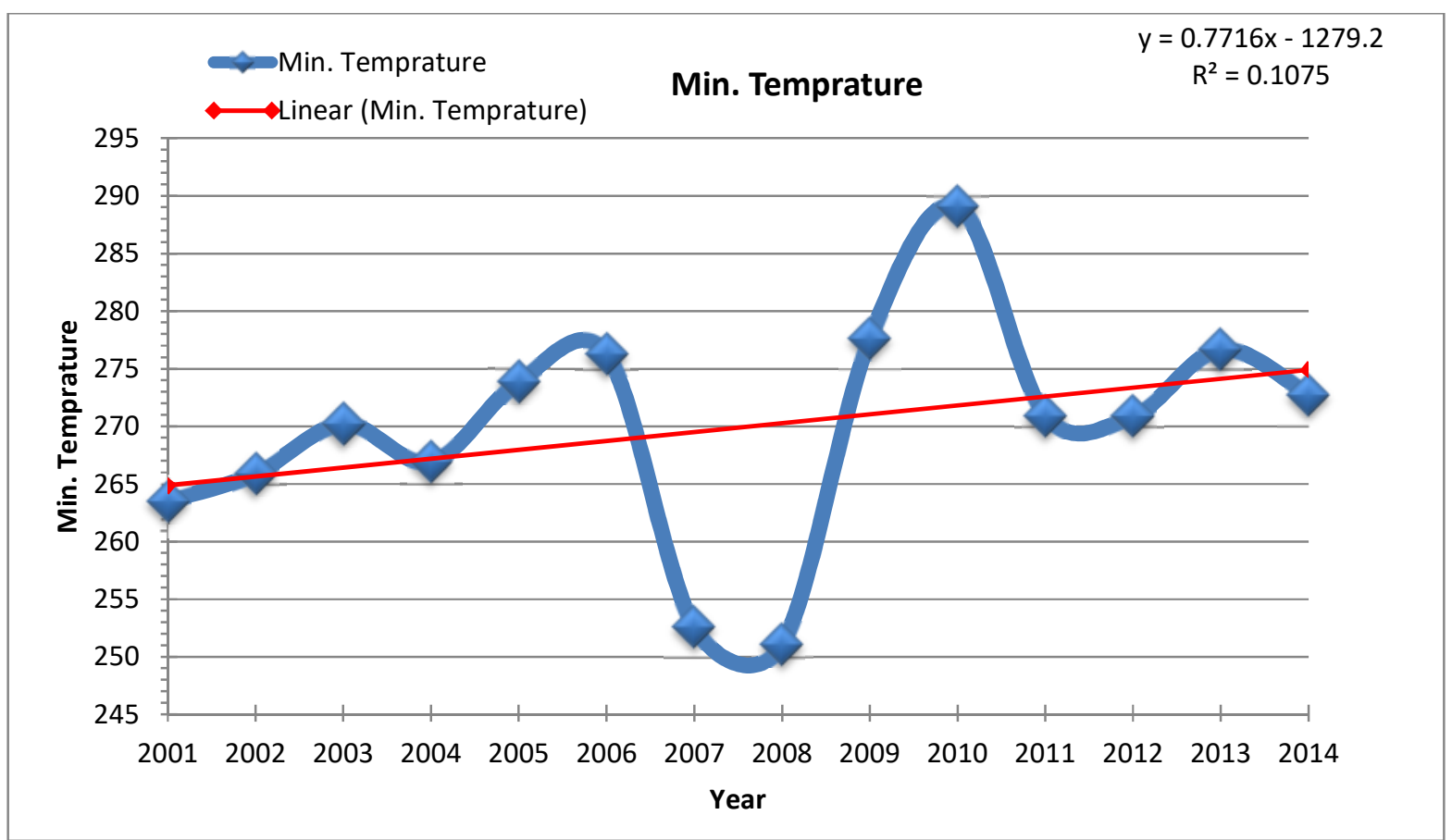

Figure 10: Minimum temperature trend in Lafia LGA. Source: field work, 2016. Source: NIMET

\subsection{Yam Production Trend in Lafia Local Government Area.}

Figure 1.5 depicts the yam production trend in Lafia Local Government Area. A careful look shows at the figure suggest an upward increase trend in yam production in the area of study over the time span. From the trend chart, it can be observed there is gradual and steady variation. The variation in production, across the years under consideration was $0.843 \%$ as indicated by the; $\mathrm{R}^{2}=0.843$.

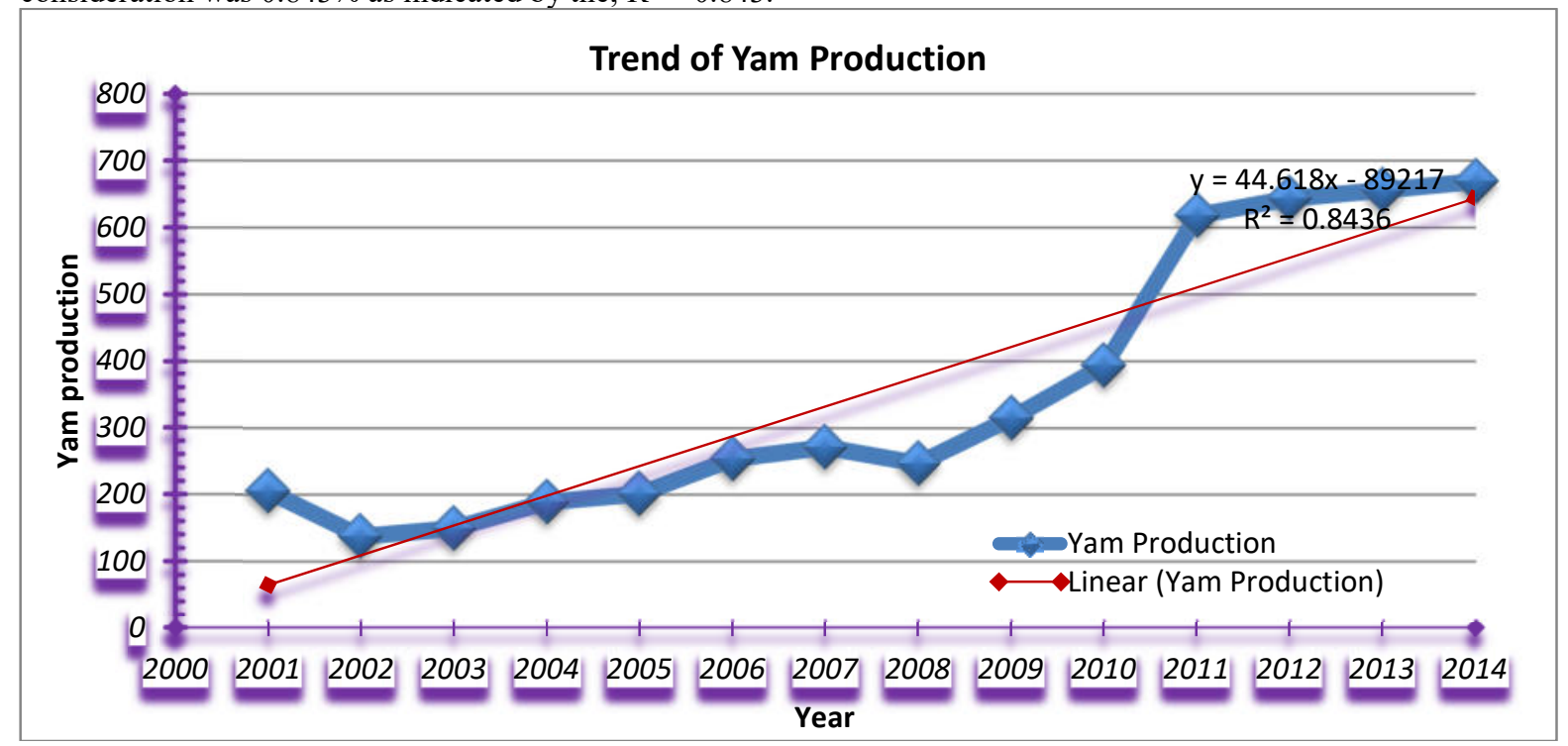

Figure 11: Yam production trend in Lafia LGA.

Source: NADP 


\subsection{Effect of Rainfall and Temperature on Yam Production in Lafia Local Government Area} Table .3: Regression Analysis of Rainfall, Temperature and Yam Production

\begin{tabular}{c|c|c|c|c|c}
\hline Variables & \multirow{2}{*}{$\begin{array}{c}\text { R-Square } \\
\left(\mathrm{r}^{2}\right)\end{array}$} & \multicolumn{2}{|c|}{ Unstandardized Coefficients } & Standardized Coefficients & \multirow{2}{*}{$\begin{array}{c}\text { Sig.(P- } \\
\text { value })\end{array}$} \\
\cline { 3 - 6 } & \multirow{2}{*}{ Constant } & $\mathrm{B}$ & Std. Error & Beta & 0.334 \\
\hline \multirow{2nnyyy}{*}{ Rainfall } & & -2871.264 & 2830.055 & & 0.438 \\
\cline { 4 - 6 } Max. Temperature & & -0.481 & 0.595 & -0.269 & 0.597 \\
\cline { 4 - 6 } Min. Temperature & & 3.022 & 5.5529 & 0.156 & 0.191 \\
\hline
\end{tabular}

a. Predictors: (Constant), Minimum Temperature, Maximum Temperature, Rainfall

b. Dependent Variable: Crop Yield (Yam)

Source: SPSS version 17 Data analysis 2016

The result extract in table .3 depicts the effect of the variation in rainfall and temperature on yam yield in the area of study. The coefficient of determination $\left(\mathrm{R}^{2}\right)$ is the proportion of the variance in the dependent variable (yam yield in this case), that is predictable from the independent variable(s) (Rainfall, Maximum and Minimum Temperature),was arrived at 0.186 . This implies that $19 \%$ of the variation in yam production is explained by the variation in rainfall, maximum and minimum temperature between the periods of 2001-2014 in Lafia Local Government Area. It is important to further state that the magnitude of effect by the predictors (rainfall, minimum and maximum temperature) on the dependent variable (yam) varies. Rainfall had a non-significant $(\mathrm{P}$-value $>0.05)$ effect of -0.269 and a coefficient value of -0.438 . This by extension implies that for every unit ( $\mathrm{mm}$ ) decrease in rainfall over the period of time under investigation, yam production decreases by $-0.438 \mathrm{mt}$.

In the same vein, maximum temperature had a non-significant $(\mathrm{P}$-value $>0.05$ ) effect of 0.156 , and a coefficient of 3.022. It thus implies that a unit increase in maximum temperature resulted to a positive effect on yam production in the study area, as production increased by $3.022 \mathrm{mt}$ per unit increase in temperature $\left(1^{\circ} \mathrm{c}\right)$. Similarly, minimum temperature had a non-significant $(\mathrm{P}$-value $>0.05)$ effect on yam yield as indicated by 0.191 significant level. The result further reveals an effect of 0.467 , with a coefficient of 9.631 . The implication here is that a unit increase in minimum temperature resulted to an increase in yam production by $9.631 \mathrm{mt}$.This also revealed that the yields may suffer significantly with either a late onset or early cessation of the growing season, as well as with a high frequency of damaging dry spells within the season, making the rainfall distribution unreliable (oladipoet, al.,2002) and (Burroughs, 2005) stated that Small changes in temperature have changed rainfall patterns in the tropics within the past two million years, making some areas drier and others wetter (Burroughs, 2005). These assertions points clearly on the importance of rains to yam development, hence any alteration of the rainfall pattern may result in negative impact on yam growth. Tina et,al., (2010) noted that, tubers such as yam would yield better when planted as early as February because it is able to absorb more heat during that time so that once the rains begin it would grow faster. Anuforom (2004) established that yam rainfall requirements are modest during the early growth.

4.5 Relationship between Rainfall, Temperature and yam production in Lafia Local Government Area

Table 4: Average Rainfall and Temperature Data with Crop Yield (2001-2014)

\begin{tabular}{ccccc}
\hline Year & $\begin{array}{c}\text { Rainfall } \\
(\mathbf{m m})\end{array}$ & $\begin{array}{c}\text { Max Temperature } \mathbf{( T} \\
\mathbf{0} \mathbf{c})\end{array}$ & $\begin{array}{c}\text { Min. Temperature } \mathbf{( T} \\
\mathbf{0} \mathbf{c})\end{array}$ & $\begin{array}{c}\text { Yam } \\
(\mathbf{m t})\end{array}$ \\
\hline 2001 & 1414.1 & 407.7 & 263.5 & 205.7 \\
2002 & 1180.9 & 412.1 & 265.9 & 137.8 \\
2003 & 1352.9 & 411.6 & 270.2 & 149.4 \\
2004 & 1305 & 407.1 & 266.9 & 189.2 \\
2005 & 1233 & 411.2 & 273.9 & 201.4 \\
2006 & 1280.1 & 414.9 & 276.3 & 253.7 \\
2007 & 1259.1 & 417.1 & 252.6 & 271.5 \\
2008 & 1124.8 & 420.7 & 251.1 & 246.8 \\
2009 & 1586.9 & 418.1 & 277.6 & 315.0 \\
2010 & 1418.3 & 416 & 289.1 & 393.4 \\
2011 & 1252.1 & 408.3 & 270.9 & 618.4 \\
2012 & 1286.3 & 403.5 & 270.9 & 643.6 \\
2013 & 1278.7 & 403.3 & 276.7 & 655.9 \\
2014 & 1254.9 & 445.6 & 272.7 & 669.2 \\
\hline
\end{tabular}

Source: Nigerian Metrological Agency and Nasarawa State Agriculture Development programme 


\begin{tabular}{|c|c|c|c|}
\hline Crop (mt) & $\begin{array}{c}\text { Rainfall } \\
(\mathrm{mm})\end{array}$ & Max Temperature $\left(\mathrm{T}^{\circ} \mathrm{c}\right)$ & Min. Temperature $\left(\mathrm{T}^{\circ} \mathrm{c}\right)$ \\
\hline Yam & -0.041 & 0.160 & 0.322 \\
\hline
\end{tabular}

Source: SPSS version 17 Data analysis 2016

The relation between rainfall, temperature and sampled crop (yam) was examined through Pearson correlation analysis as shown by the result extract in table 1 .7The result by interpretation indicates a weak negative relationship (-0.041) between rainfall and yam yield in the area of study. The results further reveal a weak positive relationship (0.160) between maximum temperature and yam yield in the study area. The relationship between the sampled crop (yam) and minimum temperature was also tested. From the result extract in the table above, there is a weak positive relationship (0.322) between minimum temperature and yam yield.

\subsection{Conclusion}

The study established that there is a minimal variability in rainfall and temperature characteristics, which translates into proportional variability in yam production in Lafia Local Government Area. The yam data was collected from the Nasarawa State Agriculture Development Programme (NADP) which was done based on the registered number of farmers, the cultivated total land of the product (yam) and its production yield of the local government area obtained for this period of study (14 years). The data were analyzed using correlation and regression analysis with the aid of the SPSS statistics package version 17, while the trend function was done with the aid of Microsoft Excel. The result shows an increase in minimum and maximum temperatures, coupled with unreliable rainfall distribution over the investigated period. The study identified increased production with non-significant positive effect of rainfall, maximum and minimum temperature on yam production. There is no doubt that tuber yield is influenced by climatic conditions (where two climatic variables- rainfall and temperature) were consider under the 14 years (2001-2014), fertile soil, quantity of planting material (seed yam) and considerable labor input and effective agronomic operation. But the variability of moisture based agro-metrological indices appears as most critical factor of yam in the humid tropic.

\section{REFERENCES}

1. Abaje I.B. Ishaya S. and Usman S.U. (2010). An Analysis of Rainfall Trends in Kafanchan, Kaduna State.Nigeria. Research Journal of Environmental and Earth Sciences 2(2): 89-96.

2. Aboki, M.P, M.A Mailafiya and P.A Osabo (2005). Vegetation and forest Resource in Geographic Perspective of Nasarawa State. Publication of the department of Geography, Nasarawa State University Keffi. Nigeria.

3. Adejuwon, J. O (1962) Crop-Climate relationship: the example of cocoa in western Nigeria. Nigeria geography journal 5 no1 22-32

4. Adejuwon, J.O. (2005). Food Crop Production in Nigeria: Present effects of Climate Variability. Climate Research, Germany, 30, P.53-60.

5. Agboola, S. A. (1979). An Agricultural Atlas of Nigeria. Oxford University Press,London.

6. Akosim O, Tella I.O, Jatau D.F (2007): Vegetation and Forest Resource in Geographic Perspective of Nasarawa State. Publication of the department of Geography,Nasarawa State University Keffi.

7. Alvaro, C. Tingju,Z. Kalrin,R. Richard, S. J. and Claudes ,R. (2009). Economy-wide Impact of Climate Change on Agriculture in Sub-Sahara Africa. International Food Policy Research Institute (IFPI) discussion paper.

8. Ayanlande, A. Odekunle, T. O, Orimongunje, O. I. Adeoye. (2009). Inter-Annual Climate Variation and Crop Yield Anomalies. Journal of Advance Natural and Applied Science

9. AIDOO, R. (2009). An analysis of yam consumption patterns in Ghanaian urban communities.Ph.D. Dissertation. Kumasi, Ghana: Department of Agricultural Economics, Agribusiness and Extension, KNUST

10. Awosika, L. French, G. Nicholls, R. and Ibe, C. (2009): "The impact of Sea level Rise on the Coastline of Nigeria”.Ewash Newspaper

11. Ayoade, J.O. (2004).Introduction to Climatology for the Tropics. Ibadan: Spectrum Books limited.

12. Ayoade, J.O. (2003). Climate Change: a synthesis of its nature causes Effects and Management. Vantage publisher, Ibadan, Oyo, Nigeria. 